\title{
Sesame Seed Yield and Growth Traits Response to Different Row Spacing in Semi-Arid Regions
}

\author{
Adam Yousif Adam Ali ${ }^{1,2, *}$, Zhou Guisheng ${ }^{2}$, Atif Hassan ${ }^{1}$, Samia Osman Yagoub ${ }^{3}$, Gafar Ali Farah ${ }^{3}$, \\ Nimir Eltyb Ahamed ${ }^{2,4}$, Aboagla Mohammed Ibrahim ${ }^{2}$, Muhi Eldeen Hussien Ibrahim ${ }^{2,3}$, \\ Mohamed Suliman $^{2,4}$, Safiya Babiker Elradi ${ }^{2,4}$, Ebtehal Gabralla Ibrahim ${ }^{2,5}$, Samia Mahgoub Omer \\ ${ }^{1}$ Department of Agronomy, Faculty of Agricultural and Environment Science, University of Gadarif, Gadarif, Sudan \\ 2 Joint International Research Laboratory of Agriculture and Agri-Product Safety, The Ministry of Education of China, Yangzhou \\ University, Yangzhou 225009, China \\ ${ }^{3}$ Department of Agronomy, College of Agricultural Studies, Sudan University of Science and Technology, Khartoum, Sudan \\ ${ }^{4}$ Department of Agronomy, Faculty of Agriculture, University of Khartoum, Khartoum, Sudan \\ ${ }^{5}$ Faculty of Forestry, University of Khartoum, Khartoum, Sudan
}

Received March 23, 2020; Revised May 28, 2020; Accepted June 19, 2020

Copyright $(\mathcal{C} 2020$ by authors, all rights reserved. Authors agree that this article remains permanently open access under the terms of the Creative Commons Attribution License 4.0 International License

\begin{abstract}
Plant density is one of the most important factors influencing the physiological, morphological characteristics, and yield of sesame. Sesame is an important oilseed and cash crop production in Sudan. The effects of different rows spacing on the growth attributes, yield and yield compound on three sesame seeds varieties were investigated at rainfall conditions in semi-arid regions. Two field experiments were conducted in 2014-2015 and 2015-2016. Three varieties were planted at four rows spacing [5(control), 10, 20 and $30 \mathrm{~cm}$ ]. The experiment was laid out in RCBD in split plots with three replications. There were significant differences between row spacing, varieties and interaction between row spacing and varieties for all parameters except the 1000 seeds weight. Moreover, Abo Nama has recorded the highest plants, number of branches and number of capsules per plant, while the abo Radom recorded the highest number of seeds per capsule and seed yield, and abo sofa had the highest weight of 1000 seeds. Planted varieties at the $5 \mathrm{~cm}$ between rows can increase the seed yield $(210.18 \mathrm{~kg} / \mathrm{h})$. The interaction between Abo Radom and control recorded the high seed yield by $265.30 \mathrm{~kg}$ per $\mathrm{h}^{-1}$. This study suggests that the appropriate rows spacing can actively increase the yield of the sesame plant.
\end{abstract}

Keywords Sesame, Plant Density, Row Spacing, Seed Yield, Yield Components

\section{Introduction}

Sesame (Sesamum indicum L.) is one of the ancient seed oil crops and is mainly grown cultivated under rainfall conditions in tropical and subtropical regions
(Pathak et al., 2014; Oyinloye et al., 2016). Among the oilseed crops, sesame has the highest oil, protein contents and carbohydrates (Raja et al., 2007; Wei et al., 2015). Sesame oil contains essential antioxidants such as sesamin and sesamolin, which prevent the rancidity (Rangkadilok et al., 2010; Mei et al., 2017). Several unsaturated fatty acids are present in sesame seeds such as linoleic and oleic acids that are mainly responsible for oil quality (Uzun et al., 2008). Sesame seeds contain all the essential amino acids, important vitamins and minerals, sesame meal contains rich amounts of fiber, ash, and carbohydrates which is extremely nutritious for livestock soap. It is also used in paints, cosmetics, perfumes and insecticides (Babaji et al., 2005).

Different environmental, genotypic, and crop management conditions (maturity group, sowing date, genotype, climate, rainfall, temperature, radiation, and physicochemical properties of the soil and the cultural practices applied in the field continuously) influence the performance of the community of plants from germination to the senescence of the plants (Agudamu et al., 2016; Pereira-Flores and Justino, 2019), and therefore can help to explain variations in yield response to plant density (Norsworthy and Frederick, 2002). For example, adverse environmental conditions limit plant plasticity, requiring an increase in plant density to offset the reduction in the branching ability (Carpenter and Board, 1997). Rainfall is the most common form of water supply, and its intensity and variability are pointed out as determinants of the risk to the success of production in most plant producing regions (Carciochi et al., 2019) Rainfall amount and distribution during the growing season are considered as the most serious environmental problems limiting crop production under rainfed conditions (Sabiel et al., 2015). 
In recent years, from 1998 to 2009, decreased the agricultural land area dropped by $0.8 \%$, we have managed to produce more yield on less land. We need to increase productivity on agricultural land by focusing on good varieties of high productivity and planting them in small areas (Food, 2011).

The seed yield of any plant is a combination of the quantitative character beneath a range of ecological factors, which perhaps influences its production. Ecological factors (climatic factors such as temperature, rainfall), and agricultural practices (such as plant populations, plant density, and sowing date) are one of the most important factors that affect the productivity of sesame plants (Geleta et al., 2002; Adebisi, 2004; Ozturk and Saman, 2012), the more important of them being the yield per plant and number of plants per area (Alegbejo et al., 2003). Adverse environmental conditions limit sesame plasticity, requiring an increase in plant density to offset the reduction in the branching ability (Carciochi et al., 2019). Plant population density has important impacts on plant growth, increase or decrease the productivity of the seed yield, increase or decrease of the plant density leads to a competition between the plants on plant nutrients in the soil (Ozturk and Saman, 2012; Fromme et al., 2019). The of suitable plant density is one of the factors that lead to the high yield of sesame (Voh, 1998). Several studies evaluated changes in yield components due to variations in plant density. These studies indicated that a decrease in plant density produces greater growth of individual plants (Luca and Hungría, 2014) and consequently more leaf area, branches, pods, and seeds per plant in soybean plants (Cox et al., 2010). However, in low productive environments, variations in per-plant leaf area and yield components at low plant density might not compensate for the lack of plants required to maximize light interception, for improving canopy photosynthesis, growth rate, and yield (Lee et al., 2008; Gaspar and Conley, 2015; Carciochi et al., 2019). Furuhata et al. (2008) reported that the seed yield increased as the row width narrowed from 80 to 60,40 , and $30 \mathrm{~cm}$, indicating the adaptability of this varieties to higher plant density. It has been reported that narrow-row cultivation not only increased the seed yield but also reduced the weed density due to more rapid canopy closure (Harder et al., 2007; Saitoh et al., 2007; Matsuo et al., 2018). Also, increases in plant density usually increase heads and kernel number per unit area and decrease kernel weight and kernels per head in the wheat plants (Valério et al., 2013; Bastos et al., 2020). Sesame growth parameters, seed yield and yield components response/influence to plant density has been reported by many researches such as Adeyemo et al. (1992) and Ngala et al. (2013), who reported that the increased of the seed productivity increase with plant population per area. Also, cultivated of the sesame plants in the wider spacing between rows lead to increase the number of capsules per plant and number of seeds per capsule (Olowe and Busari, 2003), seed weight per plant, seed index and oil, as compared with the closer spacing (Roy et al., 2009; Rahnama and Bakhshandeh, 2018). Mandal et al. (1990), who studied the relationship between plant population and the seed productivity of sesame genotype and described that the increase in the plant population lead to increasing the seed yield.

The objective of the present study was to examine the impact of plant density (adjusted by row width) on growth parameters, seed yield, and yield components for three sesame varieties under rainfall conditions. This information will provide growers with new cultivation options which will lead to more stable and higher sesame seeds yields than those obtained using conventional cultivation methods.

\section{Materials and Methods}

\subsection{Experimental Site and Soil Characteristics}

This study was performed during summer 2015 and summer 2016 at the demonstration farm, college of agricultural and environmental science, Gadarif university. To study the effect of different plant spacing between rows $(5 \mathrm{~cm}$ (control) $, 10 \mathrm{~cm}, 20 \mathrm{~cm}$ and $30 \mathrm{~cm}$ ) on the growth parameter, yield and yield component of three sesame varieties (variety Abo Radom is the high yielding, the seeds are the red and the large size, the seeds contain a high percentage of oil and protein, it is short plants and have the number of branched, and low number of leaf) variety Abo Nama (red seeds and small size, the plants of this variety change to the yellow and lacked shattering resistance, causing seeds to naturally drop onto the soil surface before harvest, also drop the leaves onto the soil surface when the plant maturity, it is longer plants and have many leaves and branches, the oil ratio is very high) and variety Abo Sofa is early maturity, and the red seeds, this variety responsive to moisture, the plants are the medium and have low number of branch and many leaf) under rain-fall condition. Gadarif city is located in the eastern of the Sudan Latitude $14^{\circ} 1^{\prime} 20^{\prime \prime} \mathrm{N}$, Longitude $35^{\circ}$ 21' 45"E, elevation $592 \mathrm{~m}$ above the sea level. The soil of the site is described by Blokhuis (1993), the soil is dark heavy cracking clay (75\%), with low organic matter and low nitrogen contents, $\mathrm{pH}$ (7.5-8), and high exchangeable sodium percentage. The climate is semi-arid, and with low relative humidity, rainfall per year is 300 to $500 \mathrm{~mm}$ in the North city and 600 to $900 \mathrm{~mm}$ in the South city. Mean temperature is $20^{\circ} \mathrm{C}$ in winter and $40^{\circ} \mathrm{C}$ in summer (Ismaeil et al., 2012).

\subsection{Experimental Design and Land Preparation}

The experiment was arranged in a randomized complete block design (RCBD) with three replications. The main 
plots were assigned for varieties, while the spacing between row constituted the sub-plots. Each variety was planted in plots $(3.5 \mathrm{~m} \times 2 \mathrm{~m})$, each plot including for 6 rows (at wider spacing of $30 \mathrm{~cm}$ ) to 18 rows (at closer spacing of $5 \mathrm{~cm}$ ), each row long 3 meters and $5,10,20$ and $30 \mathrm{~cm}$ between rows. Sowing date was carried out on the first August at 2015 and August $5^{\text {th }}$ at 2016. Weeding was done twice using hand without fertilizer and insecticide.

\subsection{Seeds Varieties}

Sesame seeds of three varieties, Abo Sofa, Abu Radom and Abo Nama were used in this study. Seeds within a variety were selected for uniform size, shape, and color. All seeds were less than 9-mo old and were previously stored in paper bags under laboratory conditions (RH 40-60\% at $15-20{ }^{\circ} \mathrm{C}$ ) to maintain good germination ability. Seeds were obtained from the Agricultural Research in Gadarif. Five seeds were planted in the hole and thing to three plants after two-week form sowing date.

\subsection{Phenotypic Characteristics}

After 90 days of sowing date, five plants from the middle of each plot were randomly selected and marked. Growth parameters were measured including plant high $(\mathrm{cm})$ and number of branches per plant.

\subsection{Yield Attributes}

At four months after planting, the five plants of each plot were harvested. Yield compound parameters were measured including number of capsules per plant and number of seeds per capsule.

\subsection{Seeds Weight (g)}

A sample of 1000-seeds was taken randomly from the yield of each plot, then weighed to determine the 1000 seed weight for each treatment.

\subsection{Seeds Yield (kg/ha)}

Plants on the one-meter length from middle of each plot of each treatment were harvested, sun-dried, weighed to obtain the biological yield. The pods of the harvested plants were threshed, and seeds were collected. The seed yield per unit area was converted into $\mathrm{kg} \mathrm{ha}^{-1}$.

\subsection{Statistical Analysis}

The data of each variable were statistically analyzed of variance for RCBD as a factorial design with the statistical package of MSTATC (Freed et al., 1991). When F values were significant, means were separated by the least significant difference (LSD) test ( $\mathrm{P} \leq 0.05$ probability) as described by Snedecor and Cochran (1980).

\section{Results and Discussion}

The results of the analysis of variance for growth phenotypic, seed yield and yield attributes are presented in Table (1). Highly significant differences among the rows spacing for all parameters. Varieties also significantly affected on most of the measures except the 1000-seeds weight. A significant affected on the interaction between varieties and rows spacing on all parameters (Table 1 and 2).

\subsection{Plant Height (cm)}

Plant height was increased by rows spacing increase as compared with the control. At the highest row spacing of $30 \mathrm{~cm}$ was significantly increased plant height by $14.23 \%$ as compare with $5 \mathrm{~cm}$ (Fig 1a). Abo Nama had the taller plant height (Table 3 ). In the interaction between rows spacing and varieties, Abo Nama at $30 \mathrm{~cm}$ was increased the plant height by $21.55 \%$ as compare with Abo Radom at $5 \mathrm{~cm}$ (Fig 1b). Maybe, the long time between the rain (increase drought period) on the later growth period lead to the competition between the plant in soil moisture and nutrients with increasing the number of the plant in the area to perform photosynthesis. Many studies indicated that the increase plant height linked to decreased the spacing between rows. The biggest spacing between the rows lead to the lesser competition between plants for available nutrients and other growth resources (Olowe and Busari, 1994; Ngala et al., 2013). These results are in agreement with the Caliskan et al. (2004), Ijoyah et al. (2015), Ngala et al. (2013) in sesame and Dugje and Odo (2006) in the millet.

\subsection{Number of Branches Per Plant}

Sesame at the wider space within row receipting maximum sunlight for the process of photosynthesis, increased photosynthesis lead to increasing the plant growth, biomass and the number of branches per plant (Idoko et al., 2018). In our study, at the control $(5 \mathrm{~cm})$, all varieties produced the lower number of branches per plant decreased by $23.99 \%$ as compared with $30 \mathrm{~cm}$ (Fig 2a). In the interaction between varieties and rows spacing, at the $30 \mathrm{~cm}$, Abo Nama and Abo Radom recorded the big number of branches per plant (Fig 2b). This result agreement with Idoko et al. (2018), who reported that reducing the space within row had negatively influences the growth parameter and productivity of seeds sesame, and also agreement with the resulting of Oad et al. (2002) in sunflower. While this result was in disagreement with the Tiwari et al. (1994), who reported that the better growth parameters of sesame show at the closer spacing within rows. Abo Nama and abo Radom increased the number of branches per plant by $64.9 \%$ as compared with abo Sofa (Table 3). 
(a)

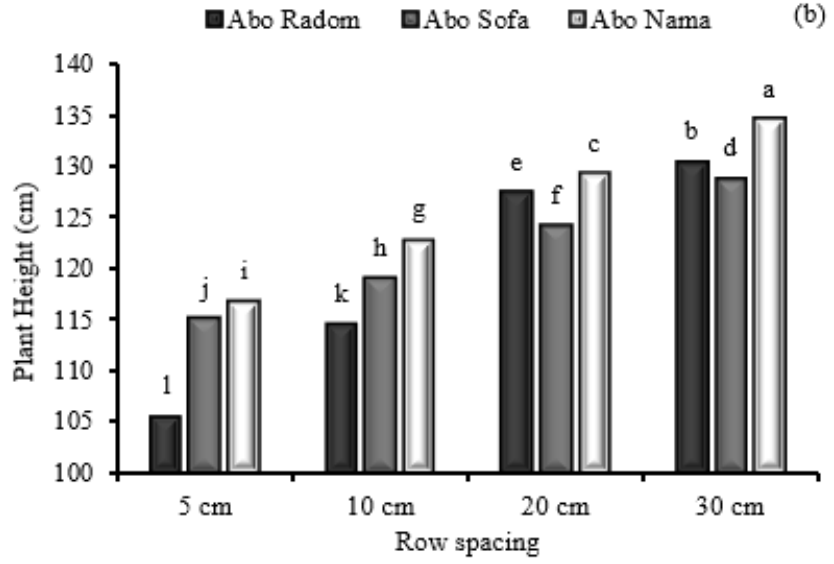

Figure 1. Effects of: (a) rows spacing and (b) interaction between varieties and rows spacing on plant height of sesame seeds varieties under rainfed condition. Bars with different letters are statistically different at $P=0.01$
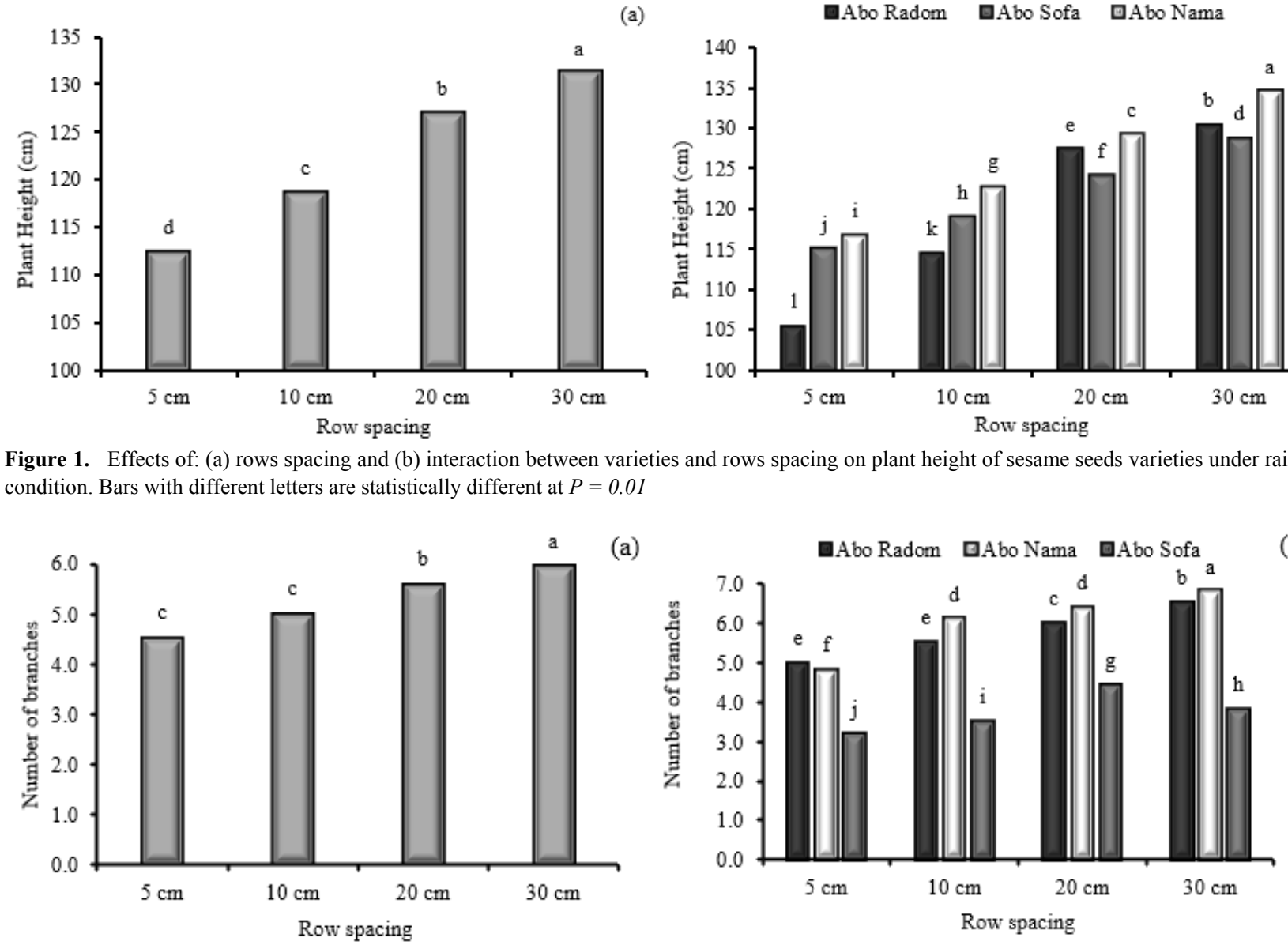

(b)

Figure 2. Effects of: (a) rows spacing and (b) interaction between varieties and rows spacing on number of branches per plant of sesame seeds varieties under rainfed condition. Bars with different letters are statistically different at $P=0.01$.

Table 1. Summary of analysis of variance for effects of Varieties (V), Row spacing (RS) and their interaction on sesame growth and yield parameters under rainfed condition at 2014 and 2015

\begin{tabular}{|c|c|c|c|c|c|c|c|c|c|c|c|c|}
\hline \multirow{3}{*}{ Source } & \multicolumn{12}{|c|}{ F value } \\
\hline & \multicolumn{2}{|c|}{ Plant Height } & \multicolumn{2}{|c|}{$\begin{array}{c}\text { Number of } \\
\text { branches }\end{array}$} & \multicolumn{2}{|c|}{$\begin{array}{c}\text { No. capsule per } \\
\text { plant }\end{array}$} & \multicolumn{2}{|c|}{$\begin{array}{c}\text { No. seeds per } \\
\text { capsule }\end{array}$} & \multicolumn{2}{|c|}{$\begin{array}{l}\text { Weight of } 1000 \\
\text { seeds }\end{array}$} & \multicolumn{2}{|c|}{$\begin{array}{l}\text { Weight of Seed } \\
\text { yield }\end{array}$} \\
\hline & 2014 & 2015 & 2014 & 2015 & 2014 & 2015 & 2014 & 2015 & 2014 & 2015 & 2014 & 2015 \\
\hline Replication & 66.03 & 1.63 & 800.4 & 7.38 & 166.5 & 475.4 & 65.71 & 60.99 & 224.9 & 0.24 & 13.08 & 12.68 \\
\hline $\begin{array}{l}\text { Varieties } \\
\text { (V) }\end{array}$ & $56.63^{* *}$ & $26.09^{* *}$ & $105.3^{* * *}$ & $9.82^{*}$ & $147.1^{* * *}$ & $187.4^{* * *}$ & $30.39^{* *}$ & $24.15^{* *}$ & $0.26^{\mathrm{ns}}$ & $1.60^{\mathrm{ns}}$ & $333^{* * *}$ & $5.43^{*}$ \\
\hline $\begin{array}{c}\text { Row } \\
\text { spacing (R) }\end{array}$ & $145.8^{* * *}$ & $418.8^{* * *}$ & $92.04^{* * *}$ & $9.41^{* * *}$ & $121.9^{* * *}$ & $249.4^{* * *}$ & $69.86^{* * *}$ & $161.1^{* * *}$ & $44.63^{* * *}$ & $17.13^{* * *}$ & $523.8^{* * *}$ & $4.39^{*}$ \\
\hline $\mathrm{V} \times \mathrm{R}$ & $10.71^{* * *}$ & $3.38^{*}$ & $17.22^{* * *}$ & $0.39^{\mathrm{ns}}$ & $29.28^{* * *}$ & $6.87^{* * *}$ & $3.66^{*}$ & $42.84^{* * *}$ & $9.44^{* * *}$ & $3.79^{*}$ & $277.67^{* * *}$ & $8.84^{* * *}$ \\
\hline
\end{tabular}

Note: NS, no significance; *, low significance at $P \leq 0.05$; $^{*}$, medium significance at $P \leq 0.01 ; * * *$, high significance at $P \leq 0.001$.

Table 2. Summary of analysis of variance showing the average of two seasons for effects of Varieties (V), Row spacing (RS) and their interaction on sesame growth and yield parameters under rainfed condition

\begin{tabular}{ccccccc}
\hline \multirow{2}{*}{ Source } & \multicolumn{9}{c}{ Mean square } \\
\cline { 2 - 7 } & \multirow{2}{*}{ Plant Height } & $\begin{array}{c}\text { No. branches per } \\
\text { plant }\end{array}$ & $\begin{array}{c}\text { No. capsule per } \\
\text { plant }\end{array}$ & $\begin{array}{c}\text { No seeds per } \\
\text { capsule }\end{array}$ & $\begin{array}{c}1000 \text { seeds } \\
\text { Weight }\end{array}$ & $\begin{array}{c}\text { Weight of Seed } \\
\text { yield }\end{array}$ \\
\hline Replication & 294.54 & 49.11 & 290.18 & 328.34 & 109.56 & 30055.2 \\
Row spacing (R) & $632.48^{* * *}$ & $3.71^{* * *}$ & $197.57^{* *}$ & $144.57^{* *}$ & $0.54^{*}$ & $8919.3^{* *}$ \\
Varieties (V) & $122.16^{* *}$ & $23.65^{* * *}$ & $5.36^{* * *}$ & $79.69^{* *}$ & $0.56^{\text {ns }}$ & $10310.2^{* *}$ \\
V×R & $27.34^{* * *}$ & $0.503^{* * *}$ & $23.58^{*}$ & $18^{*}$ & $0.80^{* *}$ & $2145.4^{*}$ \\
\hline CV\% & 0.06 & 2.49 & 1.09 & 1.28 & 2.20 & 1.24 \\
\hline
\end{tabular}

Note: ${ }^{*}$ low significance at $P \leq 0.05 ; * *$, medium significance at $P \leq 0.01 ; * * *$, high significance at $P \leq 0.001$. 
Table 3. The average of two seasons (2014 and 2015) plant height (cm), number of branches per plant, number of capsules per plant, number of seeds per capsule, weight of 1000 seeds $(\mathrm{g})$ and weight of seeds yield $(\mathrm{kg} / \mathrm{ha})$ of three varieties of sesame as influenced by different row spacing under rainfed condition.

\begin{tabular}{|c|c|c|c|c|c|}
\hline Varity & Plant Height (cm) & Number of branches & $\begin{array}{c}\text { No. capsule per } \\
\text { plant }\end{array}$ & $\begin{array}{c}\text { No. seeds per } \\
\text { capsule }\end{array}$ & $\begin{array}{c}\text { Weight of Seed } \\
\text { yield }\end{array}$ \\
\hline Abo Radom & $119.5 \mathrm{c}$ & $6.1 \mathrm{~b}$ & $30.96 b$ & $68.5 \mathrm{a}$ & $197.8 \mathrm{a}$ \\
\hline Abo Sofa & $121.8 b$ & $3.7 \mathrm{~b}$ & $32.04 \mathrm{a}$ & $64.2 \mathrm{c}$ & $156.6 \mathrm{~b}$ \\
\hline Abo Nama & $125.8 \mathrm{a}$ & $6.1 \mathrm{a}$ & $32.21 \mathrm{a}$ & $63.9 b$ & $146.3 \mathrm{c}$ \\
\hline Mean & 122.3 & 5.3 & 31.74 & 65.5 & 166.9 \\
\hline LSD & $2.64^{* *}$ & $0.39^{* * *}$ & $2.26^{* * *}$ & $2.53^{* *}$ & $1.03^{* * *}$ \\
\hline
\end{tabular}

Note: ${ }^{* *}$, medium significance at $P \leq 0.001 ; * * *$, high significance at $P \leq 0.0001$. Within the same column, means followed by the same letters are not statistically different at $P \leq 0.05$.
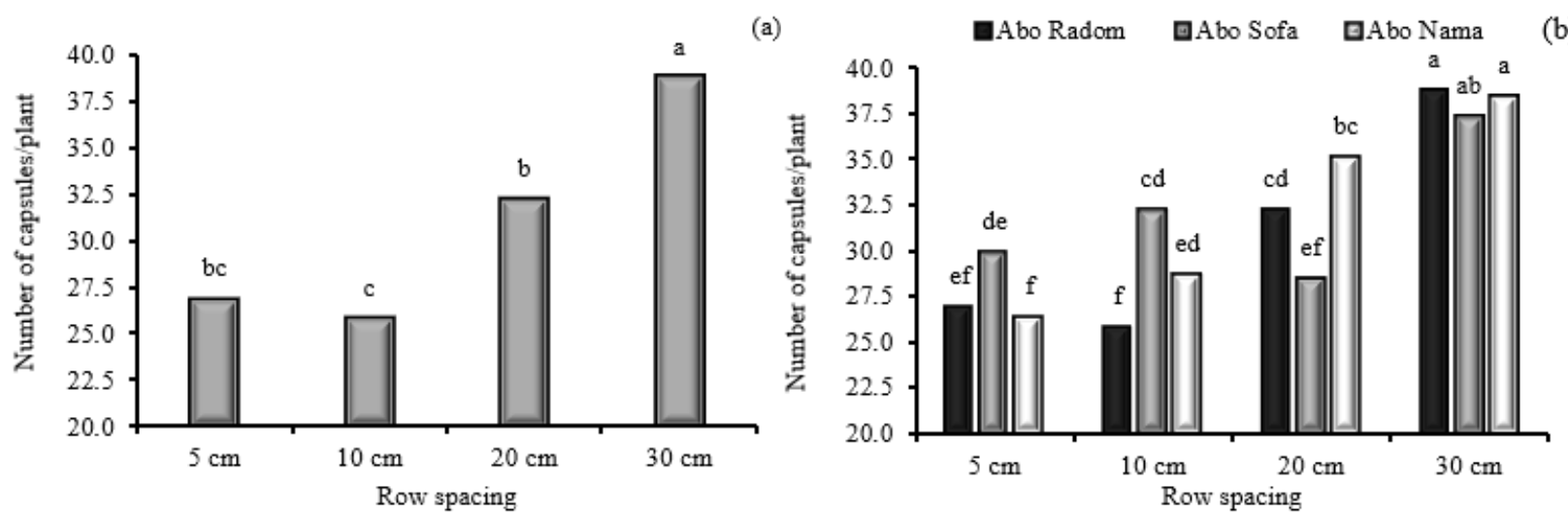

Figure 3. Effects of: (a) rows spacing and (b) interaction between varieties and rows spacing on number of capsules per plant of sesame seeds varieties under rainfed condition. Bars with different letters are statistically different at $P=0.01$

\subsection{Number of Capsules Per Plant}

Number of capsules per plant was increased by rows spacing increase as compared with the control. At the highest row spacing of $30 \mathrm{~cm}$ was significant increasing the number of capsules per plant by $16.83 \%, 33.30 \%$ and $30.54 \%$ as compare with $20 \mathrm{~cm}, 10 \mathrm{~cm}$ and $5 \mathrm{~cm}$, respectively (Fig 3a). Abo Nama and Abo Sofa produced the highest number of capsules per plant, while the Abo Radom had the lowest number of capsules per plant (Table $3)$. In term of interaction between varieties and rows spacing, at $30 \mathrm{~cm}$ Abo Nama and Abo Radom was recorded the highest number of capsules, while the same varieties at $5 \mathrm{~cm}$ had the lowest capsules per plant (Fig 3b). The reduction of the number of capsules per plant might be due to the extreme limitation of spacing and leaves for the formation and development of capsules. Many researches stated that the decreased within plant spacing at row reduced the number of capsules per plant, might be attributed to narrow spacing between plants and increase interplant competition in nutrition (Roy et al., 2009). These results are in agreement with Subrahmaniyan and Arulmozhi (1999), Tiwari et al. ( 2000) and Roy et al. (2009) who reported that the number of capsules per plant was increased by increasing the plant spacing.

\subsection{Number of Seeds Per Capsule}

At the $30 \mathrm{~cm}$ was increased the number of seeds per capsules by $12.04 \%$ as compare with $5 \mathrm{~cm}$ (Fig. 4a). Abo Radom produced the biggest number of seeds per capsules (Table 3). In term of interaction between varieties and rows spacing, Abo Radom and Abo Sofa at $30 \mathrm{~cm}$ had the highest number of seeds per capsule, while the Abo Sofa and Abo Nama at $5 \mathrm{~cm}$ recorded the lowest number of seeds per plant (Fig 4b). This work confirms the earlier work reported by Jakusko et al. (2013), who stated that the number of seeds per capsule significantly increased with increasing the rows spacing. These findings also are in line with Kathiresan (2002), who stated that reduction in row spacings increased intra-specific competition which finally caused a decrease in the number of seeds per capsules compared with wider spacing. Our results in disagreement with Ahmed et al., (2010) who mentioned that the number of capsules per plant reduction at the closer rows spacing (increasing plant densities). These results may be attributed to the reduced competition between plants and between the different parts of the individual plant under the wide rows spacing. 


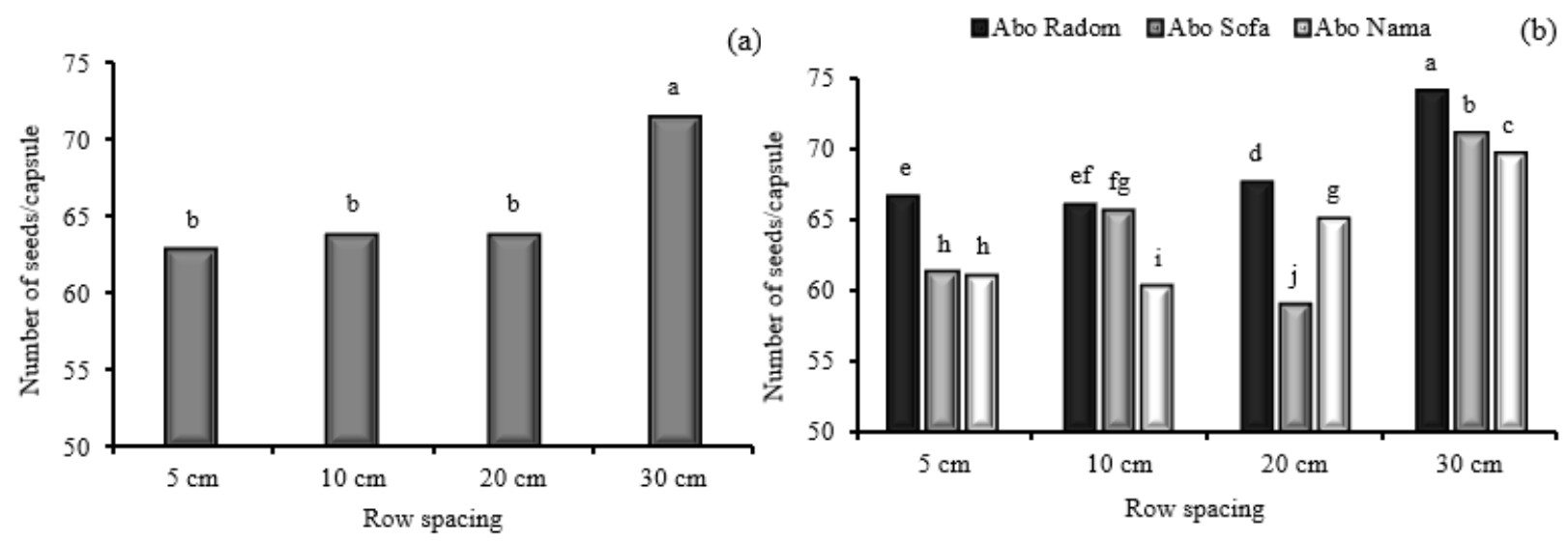

Figure 4. Effects of: (a) rows spacing and (b) interaction between varieties and rows spacing on number of seeds per plant of sesame seeds varieties under rainfed condition. Bars with different letters are statistically different at $P=0.01$.
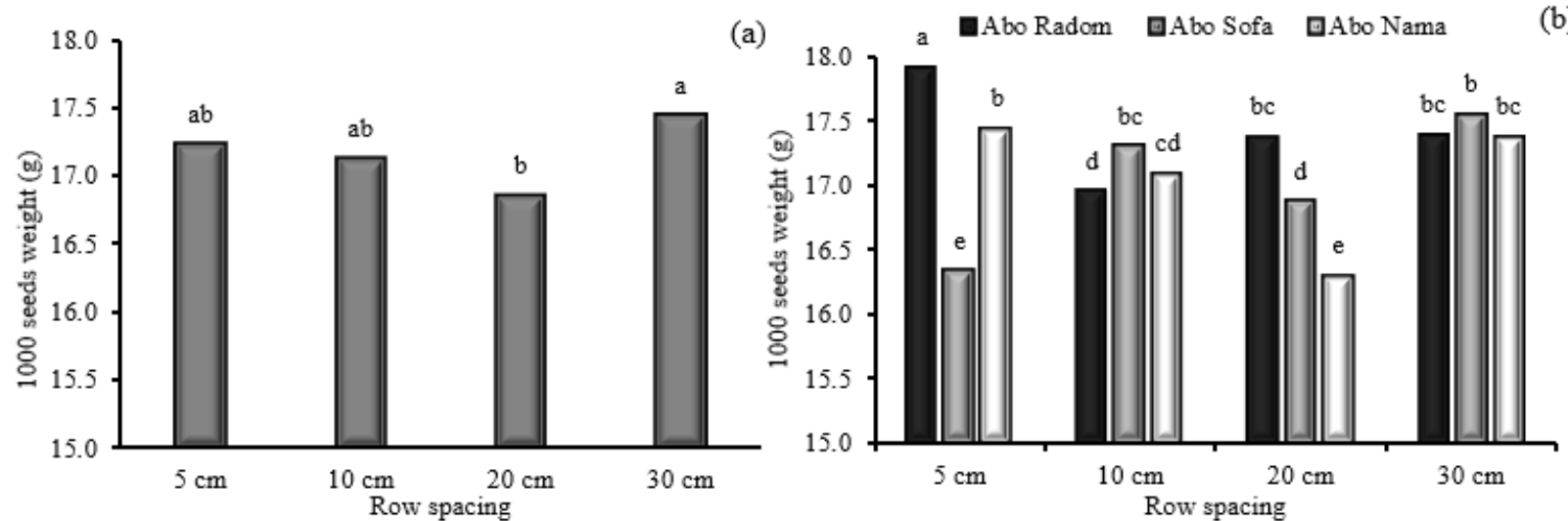

Figure 5. Effects of: (a) rows spacing and (b) interaction between varieties and rows spacing on 1000 seeds weight (g) of sesame seeds varieties under rainfed condition. Bars with different letters are statistically different at $P=0.01$.

\subsection{Seeds Weight $(\mathrm{g})$}

Compared to the control, the 1000 seeds weight increased with the increase of rows spacing. The big weight

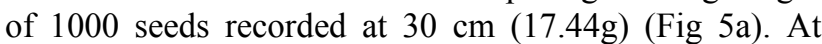
control, Abo Radom recorded the higher weight of 1000 seeds by $17.92 \mathrm{~g}$, and Abo Nama registered the lowest weight of 1000 seeds at the same spacing (Fig 5b). Olowe and Busari (2003), who stated that 1000 seeds weight was increasing 1000 seeds weight at the wide rows spacing compare with the narrower spacing, this may be due to increase the plant population lead to reduces the seed size, this result disagreement between our result.

\subsection{Seed Yield (kg/ha)}

Compared to the control, the seeds yield decreased with the increase of rows spacing. The seeds yield was decreased by $34.20 \%$ in $30 \mathrm{~cm}$ as compared with control (Fig 6a). Abo Radom produced the highest seeds yield by $197.83 \mathrm{~kg}$ per ha ${ }^{-1}$, whereas the Abo Nama was recorded the lowest seeds yield by $146.31 \mathrm{~kg} \mathrm{per} \mathrm{ha}^{-1}$ (Table 3 ). Abo Radom at $5 \mathrm{~cm}$ had the biggest weight of seeds yield, while Abo Nama at $30 \mathrm{~cm}$ was recorded the lowest seeds yield (Fig 6b). Ozturk and Saman (2012), who reported that the highest plant population density lead to increase yield productivity, may be due to the highest number of plants per area in closer rows spacing or hills on row, could compensate that decreasing in the yield component of the plant such as the weight of 1000 seeds, seeds weight and number of capsules per plant. In this study, it was found that wider row spacings reduced the seeds yield, but increasing the plant population on the closer spacing increase the seed productivity. Similar result was mentioned by Channabasavanna and Setty (1992), stated that the increase plant density per ha ${ }^{-1}$ lead the increasing yield productivity. Also, Adeyemo et al. (1992), Chimanshette and Dhoble (1992), Tiwari et al. (1994), Basavaraj et al. (2000), Imayavaramban et al. (2002), Caliskan et al. (2004), and Ojikpong et al. (2007), wherein they noted to get to the higher seeds productivity when the grown plant on the high plant density. These results are in disagreement with those studies by Ahmad et al. ( 2002), Rahnama and Bakhshandeh (2018) and Carciochi et al. (2019), who observed that the planting sesame and soybean on the wider planting distance produced the highest seeds productivity. Also, this result dissimilarly with Ahmed et al., (2010) pointed that seed yield substantially decreased with increasing plant population (at the wide row spacing). 

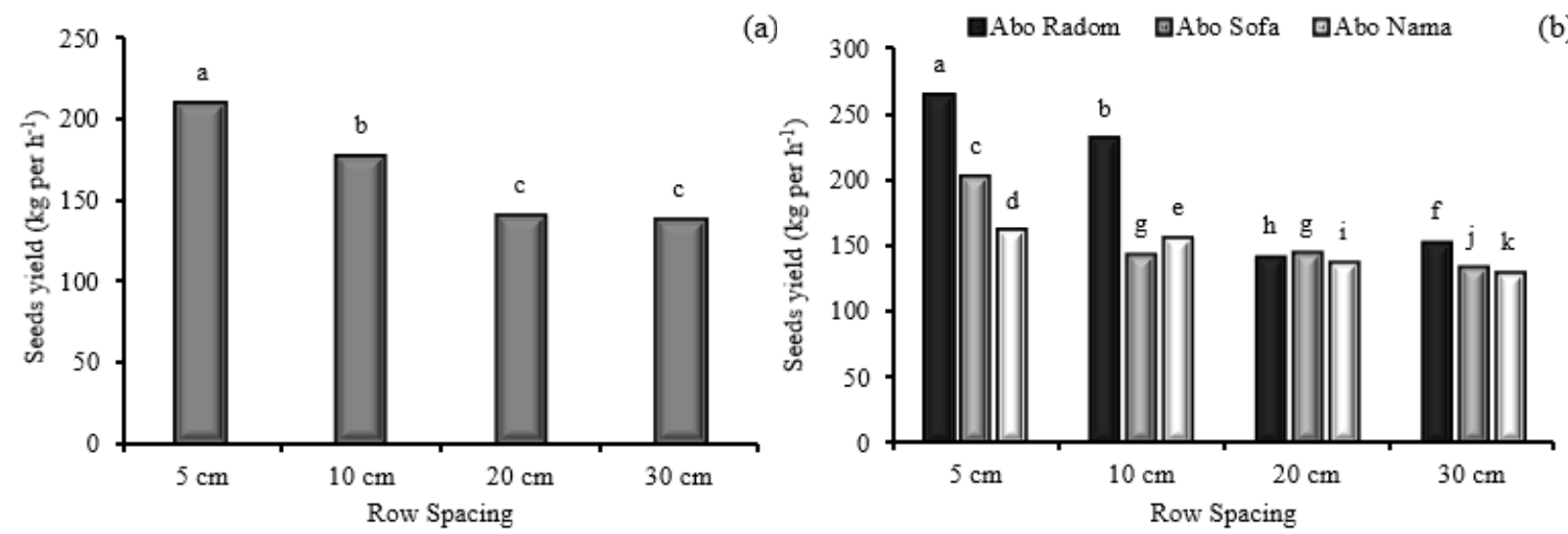

Figure 6. Effects of: (a) rows spacing and (b) interaction between varieties and rows spacing on weight of seed yield (kg/ha) of sesame seeds varieties under rainfed condition. Bars with different letters are statistically different at $P=0.01$

\section{Conclusions}

The most probable agronomic optimal plant density depended on the yield environment. With the plant density increased ( $5 \mathrm{~cm}$ between rows) the seeds yield increased, while decreased by $15.5 \%, 32.7 \%$ and 37.0 in $10 \mathrm{~cm}, 20 \mathrm{~cm}$ and $30 \mathrm{~cm}$ between rows relative to $5 \mathrm{~cm}$. The results concluded that growth parameter, yield and yield component were the highly significant difference affected by the row spacing and row spacing and interaction between them. Reducing the row spacing decreased the growth parameter and yield component. All varieties at 5 $\mathrm{cm}$ recorded the high seed yield. The interaction between abo Radom and $5 \mathrm{~cm}$ in 2014 and Abo sofa with $5 \mathrm{~cm}$ in 2015 recorded the high seed yield. Abo Radom is the best variety grown at $5 \mathrm{~cm}$. As evidenced by the result of the field experiment to include row spacing and different genotype. Based on this, a farmer may select different plant density with varying levels of spacing between plants, and good genotypes depending on the yield environments, could be used to decrease weather-related production risk.

\section{REFERENCES}

[1] Adebisi M.A. 2004. Variation, stability and correlation studies in seed quality and yield of sesame (Sesamum Indicum L.). PhD thesis. Department of Plant Breeding and Seed Technology, Federal University of Agriculture, Abeokuta, Ogun State, Nigeria. 132 pp.

[2] Adeyemo, M.O., A.O. Ojo, and D.T. Gungula. 1992. Effects of plant population on some agronomic traits and seed yield of sesame. Oilseeds J 1: 35-42.

[3] Agudamu, T. Yoshihira, and T. Shiraiwa. 2016. Branch development responses to planting density and yield stability in soybean cultivars. Plant Production Science 19(3): 331339.

[4] Ahmad, Tariq Mahmood, M. Farrukh Saleem and Shamim Ahmad , 2002. Comparative Performance of Two Sesame
(Sesamum indicum L.) Varieties under Different Row Spacings. Asian Journal of Plant Sciences, 1: 546-547.

[5] Ahmed, M. E., M.E. Entisar, and A.A. Awad. 2010. Effect of plant density on the performance of some sesame (Sesamum indicum L.) cultivars under Rain fed. Research Journal of Agriculture and Biological Sciences 6(4): 498-504.

[6] Alegbejo, M.D., G.A. Iwo, M.E. Abo, and A.A. Idowu. 2003. Sesame: A potential industrial and export oilseed crop in Nigeria. Journal of Sustainable Agriculture 23(1): 59-76.

[7] Babaji, B.A., I.M. Haruna, and A.A. Mukhtar. 2005. Sesame (Sesamum indicum L.): An oil boom for Northern Nigeria. In National Conference on Development of Agriculture in the Northern Nigeria, Organized on June 29th-July 2nd.

[8] Basavaraj, B., R.A. Shetty, S.G. Patil, and C.S. Hunshal. 2000. Nutrient content and upake by sesame varieties as influenced by fertilizer and population levels under summer irrigated conditions. Karnataka Journal of Agricultural Sciences 13(1): 141-143.

[9] Bastos, L.M., W. Carciochi, R.P. Lollato, B.R. Jaenisch, C.R. Rezende, R. Schwalbert, P. V Vara Prasad, G. Zhang, A.K. Fritz, and C. Foster. 2020. Winter wheat yield response to plant density as a function of yield environment and tillering potential: A review and field studies. Frontiers in Plant Science 11: 54 .

[10] Blokhuis, W.A. 1993. Vertisols in the central clay plain of the Sudan. Agricultural University.

[11] Caliskan, S., M. Arslan, H. Arioglu, and N. Isler. 2004. Effect of planting method and plant population on growth and yield of sesame (Sesamum indicum L.) in a Mediterranean type of environment. Asian J. Plant Sci 3(5): 610-613.

[12] Carciochi, W.D., R. Schwalbert, F.H. Andrade, G.M. Corassa, P. Carter, A.P. Gaspar, J. Schmidt, and I.A. Ciampitti. 2019. Soybean seed yield response to plant density by yield environment in North America. Agronomy Journal 111(4): 1923-1932.

[13] Carpenter, A.C., and J.E. Board. 1997. Growth dynamic factors controlling soybean yield stability across plant populations. Crop Science 37(5): 1520-1526.

[14] Channabasavanna, A.S., and R.A. Setty. 1992. Response of 
sesame (Sesamum indicum L.) genotypes to plant densities under summer conditions. Indian Journal of Agronomy 37(3): 601-602.

[15] Chimanshette, T.G., and M. V Dhoble. 1992. Effect of sowing date and plant-density on seed yield of sesame (Sesamum indicum L.) varieties. Indian Journal Of Agronomy 37(2): 280-282.

[16] Cox, W.J., J.H. Cherney, and E. Shields. 2010. Soybeans compensate at low seeding rates but not at high thinning rates. Agronomy journal 102(4): 1238-1243.

[17] Dugje, I.Y., and P.E. Odo. 2006. Variety and inter-row spacing influence on direct estimation of leaf area index of pearl millet. Journal of Sustainable Tropical Agricultural Research 18: 27-34.

[18] Food, U.N. 2011. The state of the world's land and water resources for food and agriculture managing systems at risk. Published by: The Food and Agriculture Organization of the United Nations and Earthscan

[19] Freed, R., S.P. Eisensmith, E. Everson, M. Weber, E. Paul, and E. Isleib. 1991. MSTAT-C: A Microcomputer Program for the Design, Management, and Analysis of Agronomic Research Experiments. Michigan State University: East Lancing, MI.

[20] Fromme, D.D., T.A. Spivey, and W.J. Grichar. 2019. Agronomic response of corn (Zea mays L.) hybrids to plant populations. International journal of agronomy. Volume 2019, Article ID 3589768, 8 pages.

[21] Furuhata, M., H. Morta, and H. Yamashita. 2008. Performances of dry matter and seed production under narrow-row-dense-planting culture of soybean cultivar, Sachiyutaka, in South-Western Japan. Japanese Journal of Crop Science .77(4):409-417.

[22] Gaspar, A.P., and S.P. Conley. 2015. Responses of canopy reflectance, light interception, and soybean seed yield to replanting suboptimal stands. Crop Science 55(1): 377-385.

[23] Geleta, B., M. Atak, P.S. Baenziger, L.A. Nelson, D.D. Baltenesperger, K.M. Eskridge, M.J. Shipman, and D.R. Shelton. 2002. Seeding rate and genotype effect on agronomic performance and end-use quality of winter wheat. Crop Science 42(3): 827-832.

[24] Harder, D.B., C.L. Sprague, and K.A. Renner. 2007. Effect of soybean row width and population on weeds, crop yield, and economic return. Weed Technology 21(3): 744-752.

[25] Idoko, P. Baba, and T. Ugoo. 2018. Effect of inter-row and intra-row spacing on the growth and yield of sesame (Sesamum indicum L.) in Makurdi, Nigeria. International Journal of Agronomy and Agricultural Research 12, No. 1(2223-7054): 69-76.

[26] Ijoyah, M.O., J.A. Idoko, and T. Iorlamen. 2015. Effects of intra-row spacing of sezame (Sesamum indicum L.) and frequency of weeding on yields of maize-sesame intercrop in Makurdi, Nigeria. International Letters of Natural Sciences. 38: 16-26.

[27] Imayavaramban, V., K. Thanunathan, R. Singaravel, and G. Manickam. 2002. Studies on the influence of integrated nutrient management on growth, yield parameters and seed yield of sesame (Sesamum indicum L.). Cropp Research
Hisar 24(2): 309-313.

[28] Ismaeil, F.M., A.O. Abusuwar, and A.M. El Naim. 2012. Influence of chicken manure on growth and yield of forage sorghum (Sorghum bicolor L. Moench). International Journal of Agriculture and Forestry 2(2): 56-60.

[29] Jakusko, B.B., B.D. Usman, and A.B. Mustapha. 2013. Effect of row spacing on growth and yield of sesame (Sesamum indicum L.) in Yola, Adamawa State, Nigeria. Journal of Agriculture and Veterinary Science 2(3): 36-39.

[30] Kathiresan, G. 2002. Response of sesame (Sesamum indicum L.) genotypes to levels of nutrients and spacing under different seasons. Indian Journal of Agronomy 47(4): 537540 .

[31] Lee, C.D., D.B. Egli, and D.M. TeKrony. 2008. Soybean response to plant population at early and late planting dates in the Mid-South. Agronomy Journal 100(4): 971-976.

[32] Luca, M.J. de, and M. Hungría. 2014. Plant densities and modulation of symbiotic nitrogen fixation in soybean. Scientia Agricola 71(3): 181-187.

[33] Mandal, S.S., S.K. Das, S.B. Goswami, and B.K. Pradhan. 1990. Yield and yield attributes of sesame as influenced by potassium nutrition and plant density. Indian Agriculturist 34(2): 99-102.

[34] Matsuo, N., T. Yamada, Y. Takada, K. Fukami, and M. Hajika. 2018. Effect of plant density on growth and yield of new soybean genotypes grown under early planting condition in southwestern Japan. Plant Production Science 21(1): 16-25.

[35] Mei, H., Y. Liu, Z. Du, K. Wu, C. Cui, X. Jiang, H. Zhang, and Y. Zheng. 2017. High-density genetic map construction and gene mapping of basal branching habit and flowers per leaf axil in sesame. Frontiers in plant science 8: 636.

[36] Ngala, A.L., I.Y. Dugje, and H. Yakubu. 2013. Effects of inter-row spacing and plant density on performance of sesame (Sesamum indicum L.) in a nigerian Sudan Savanna. Science International (Lahore) 25(3): 513-519.

[37] Norsworthy, J.K., and J.R. Frederick. 2002. Reduced seeding rate for glyphosate-resistant, drilled soybean on the southeastern Coastal Plain. Agronomy Journal 94(6): 1282 1288 .

[38] Oad, F.C., M.A. Samo, S.M. Qayyum, and N.L. Oad. 2002. Inter and intra row spacing effect on the growth, seed yield and oil content of safflower (Carthamus tinctorius L.). Asian Journal of Plant Sciences 1(1): 18-19.

[39] Ojikpong, T.O., D.A. Okpara, and C.O. Muoneke. 2007. Effect of plant spacing and sowing date on Sesame (Sesamum indicum L.) production in south Eastern Nigeria. Nigeria Agricultural Journal 38(1): 12-23.

[40] Olowe, V.I.O., and L.D. Busari. 1994. Appropriate plant population and spacing for sesame (Sesamum indicum L.) in the Southern Guinea Savanna of Nigeria. Trop. Oil Seeds J 2: $18-27$.

[41] Olowe, V.I.O., and L.D. Busari. 2003. Growth and grain yield of two sesame (Sesamum indicum L.) varieties as affected by row spacing in Southern Guinea savanna of Nigeria. Samaru J. Agric. Res 19: 91-101. 
[42] Oyinloye, B.E., B.O. Ajiboye, O.A. Ojo, S.O. Nwozo, and A.P. Kappo. 2016. Cardioprotective and antioxidant influence of aqueous extracts from Sesamum indicum (L) seeds on oxidative stress induced by cadmium in wistar rats. Pharmacognosy magazine 12(Suppl 2): S170.

[43] Ozturk, O., and O. Saman. 2012. Effects of different plant densities on the yield and quality of second crop sesame. World Academy of Science, Engineering and Technology, International Journal of Biological, Biomolecular, Agricultural, Food and Biotechnological Engineering 6(9): 644-649.

[44] Pathak, N., A.K. Rai, R. Kumari, A. Thapa, and K.V. Bhat. 2014. Sesame crop: an underexploited oilseed holds tremendous potential for enhanced food value. Agricultural Sciences 5(06): 519.

[45] Pereira-Flores, M.E., and F.B. Justino. 2019. Yield Components and Biomass Partition in Soybean: Climate Change Vision. In Soybean-Biomass, Yield and Productivity. IntechOpen.

[46] Rahnama, A., and A. Bakhshandeh. 2018. Determination of optimum row-spacing and plant density for uni-branched sesame in Khuzestan province.

[47] Raja, A., K.O. Hattab, L. Gurusamy, and S. Suganya. 2007. Sulphur levels on nutrient uptake and yield of sesame varieties (Sesamum indicum L.) and nutrient availability. Int. J. Soil Sci 2(4): 278-285.

[48] Rangkadilok, N., N. Pholphana, C. Mahidol, W. Wongyai, K. Saengsooksree, S. Nookabkaew, and J. Satayavivad. 2010. Variation of sesamin, sesamolin and tocopherols in sesame (Sesamum indicum L.) seeds and oil products in Thailand. Food Chemistry 122(3): 724-730.

[49] Roy, N., S.M. Abdullah-Mamun, and M. Sarwar-Jahan. 2009. Yield performance of sesame (Sesamum indicum L.) varieties at varying levels of row spacing. Research Journal of Agriculture and Biological Sciences 5(5): 823-827.

[50] Sabiel, S.A.I., M.I. Ismail, E.A. Abdalla, and A.A. Osman. 2015. Genetic variation in sesame genotypes (Sesamum indicum L.) grown in the semi-arid zone of the Sudan. SABRAO Journal of Breeding \& Genetics 47(3).

[51] Saitoh, K., K. Hirata, and Y. Kashiwagi. 2007. Effect of row-width and planting density on podding and yield performance of early soybean [Glycine $\max$ L.] cultivar'Enrei'with reference to raceme order. Japanese Journal of Crop Science (Japan).

[52] Snedecor, G.W., and W.G. Cochran. 1980. Statistical Methods Iowa State University Press, Ames. Statistical methods. 7th ed.. The Iowa State University Press, Ames.

[53] Subrahmaniyan, K., and N. Arulmozhi. 1999. Response of sesame (Sesamum indicum L.) to plant population and nitrogen under irrigated condition. Indian Journal of Agronomy (India).

[54] Tiwari, K.P., R.K. Jain, and R.S. Raghuwanshi. 1994. Effect of sowing dates and plant densities on seed yield of sesame cultivars. Crop Res. Hisar 8(2): 404-406.

[55] Tiwari, R.K., K.N. Namdeo, and J. Girish. 2000. Effect of nitrogen and sulphur on growth, yield and quality of sesame (Sesamum indicum L.) varieties. Research on Crops 1(2): 163-167.

[56] Uzun, B., C.. Arslan, and Ş. Furat. 2008. Variation in fatty acid compositions, oil content and oil yield in a germplasm collection of sesame (Sesamum indicum L.). Journal of the American Oil Chemists' Society 85(12): 1135-1142.

[57] Valério, I.P., F.I.F. de Carvalho, G. Benin, G. da Silveira, J.A.G. da Silva, R. Nornberg, T. Hagemann, H. de S. Luche, and A.C. de Oliveira. 2013. Seeding density in wheat: the more, the merrier? Scientia Agricola 70(3): 176-184.

[58] Voh, J.P. 1998. An overview of beniseed research and production in Nigeria and prospects for increased production. Beniseed in Nigeria: Opportunities for research production and marketing. Pp: 43-46.

[59] Wei, X., K. Liu, Y. Zhang, Q. Feng, L. Wang, Y. Zhao, D. Li, Q. Zhao, X. Zhu, and X. Zhu. 2015. Genetic discovery for oil production and quality in sesame. Nature Communications 6 : 8609. 